\title{
ANALISIS KESALAHAN GRAMATIKA BAHASA INDONESIA DALAM SURAT RESMI DI KANTOR DESA MAMBEN LAUK
}

\author{
Niswatul Hasanah \\ Universitas Mataram \\ Jalan Pemuda No. 35 Mataram - 83125, Lombok, NTB. \\ niswah@yahoo.com
}

\begin{abstract}
The aim of this reseach is to know the forms of grammatical error in legitimate letter especially which occour in the village district office at Mamben Lauk, focus on how the written error occour in legitimate letter. This reseach is descriptive and qualitative. The hole data in this reseach is written data of legitimate letter which made by the village district office. The source data of this research was takken from legitimate sending letter documentation. The data collection technic is Documentation Technic. The instrumen used is in this reaseach is self research to get the real data needed. The result of this reseach is from six legitimate letter was indicated the error written occour in grammatical, like in words choice, language used, capital letter, question mark, abrevation and accronim in each part of the letters. meanwhile in word choice side was found some error, the words choice and uses wasn't accurate, however in laguage uses was found the uses of language wasn't efective.
\end{abstract}

Key Words: Analysis, Grammatical, Legitimating Letter.

\begin{abstract}
ABSTRAK
Penelitian ini bertujuan untuk mengetahui bentuk-bentuk kesalahan penulisan bagian-bagian surat resmi dalam surat resmi yang dikeluarkan oleh Kantor Desa Mamben. Penelitian ini merupakan jenis penelitian deskriptif kualitatif. Data dalam penelitian ini adalah data tertulis. Sumber data penelitian ini diperoleh dari dokumentasi surat-surat keluar yang ada di Kantor Desa Mamben Lauk. Teknik pengumpulan data dilakukan dengan teknik dokumentasi. Instrumen yang digunakan dalam penelitian ini adalah peneliti sendiri yang melakukan penelitian dalam memperoleh data. Hasil penelitian kesalahan gramatika bahasa Indonesia dalam surat resmi yang dikeluarkan oleh Kantor Desa Mamben Lauk menunjukkan banyak terjadi kesalahan penulisan bentuk penggunaan ejaan, pilihan kata dan bahasa dalam tiap-tiap bagian surat resmi, mulai dari kepala surat sampai bagian tembusan. Kesalahan ejaan ditemukan dalam penulisan huruf kapital, tanda baca, penulisan kata, penulisan singkatan, akronim dan penulisan unsur serapan. Sementara itu, dari segi pilihan kata ditemukan kesalahan berupa pemakaian kata yang kurang cermat. Adapun dari segi bahasa, ditemukan penggunan bahasa yang kurang efektif.
\end{abstract}

Kata kunci: analisis, gramatika, Surat resmi. 


\section{PENDAHULUAN}

Gramatika atau tata bahasa merupakan hal pokok yang harus diketahui oleh setiap pengguna bahasa yang ingin memakai bahasa secara benar. Berbicara mengenai gramatika bahasa Indonesia, maka kita tidak akan terlepas dari peraturan EYD, Kamus Besar Bahasa Indonesia dan Tata Bahasa Baku Bahasa Indonesia.

Penggunaan gramatika bahasa Indonesia yang baik dan benar sangat dibutuhkan pada penulisan yang bersifat resmi, misalnya surat resmi. Penggunaan kaidah gramatika bahasa Indonesia yang benar dalam surat resmi harus mengikuti kaidah ejaan, pembentukan kata, penyusunan kalimat, penyusunan paragraf dan penataan penalaran. Sebaliknya, Jika kaidah ejaan digunakan secara cermat, kaidah pembentukan kata diperhatikan dengan seksama, dan penataan penalaran ditaati dengan konsisten, pemakaian bahasa Indonesia dikatakan benar. Sebaliknya jika kaidah-kaidah bahasa itu kurang ditaati, pemakaian bahasa tersebut dianggap tidak benar (Zaenal Arifin dan Farid Hadi, 2009: 12).

Surat resmi sebagai salah satu bentuk penyampaian informasi secara tertulis yang dibuat instansi pemerintah terutama surat resmi yang dikeluarkan oleh Kantor Desa Mamben Lauk sungguh memperihatinkan, karena yang seharusnya menjadi panutan masyarakat dalam penulisan menurut kaidah gramatika bahasa Indonesia yang benar, justru banyak sekali ditemukan berbagai bentuk macam kesalahan, baik kesalahan dalam penulisan ejaan, maupun kesalahan dalam hal penyusunan kalimat.

Kesalahan-kesalahan itu terjadi kemungkinan karena penulis belum paham terhadap penerapan kaidah-kaidah bahasa Indonesia yang baik dan benar. Ada tiga kemungkinan penyebab seseorang salah dalam berbahasa, antara lain 1) Terpengaruh oleh bahasa yang lebih dahulu dikuasainya (B1). 2) Kekurangpahaman pemakai bahasa terhadap bahasa yang dipakainya. 3) Pengajaran bahasa Indonesia yang kurang tepat dan kurang sempurna. Hal ini berkaitan dengan bahan yang diajarkan atau dilatihkan dan cara pelaksanaan pengajaran (Styawati, 2010: 14).

Kesalahan umum yang terjadi dalam penulisan kalimat surat resmi, misalkan di dalam paragraf penutup surat resmi seringkali ditemukan penggunaan kalimat "Demikian atas perhatian dan kebijaksanaan Bapak Pimpinan kami ucapkan diperbanyak terimakasih." (kutipan surat dinas Pertamina kepada PT Gapermigas). Agar kalimat penutup surat dinas tersebut efektif dan tidak menimbulkan ketidakjelasan 
makna, sebaiknya kalimat penutup surat dinas di atas mengatakan Atas perhatian dan kebijaksanaan Bapak, kami mengucapkan banyak terima kasih. Sedangkan, kesalahan dalam hal EYD banyak kita temukan dalam hal penggunaan tanda baca, penulisan kata dan penulisan huruf.

Melihat berbagai fenomena kesalahan-kesalahan gramatika yang terjadi pada surat resmi inilah yang menggerakkan hati penulis untuk meneliti lebih lanjut berbagai macam kesalahan gramatika yang terjadi dalam surat resmi terutama dalam hal kesalahan penulisan bagian-bagian surat resmi di Kantor Desa Mamben Lauk.

\section{TEORI DAN METODOLOGI}

Pendekatan yang digunakan dalam penelitian ini adalah penelitian kualitatif. Jenis penelitian ini bersifat kualitatif deskriptif, karena dalam penelitian ini menghasilkan data deskriptif berupa kata-kata tertulis atau lisan dari orang-orang atau perilaku yang dapat diamati (Bogdan dan Taylor dalam Moleong, 2007: 4). Data yang akan dijaring dalam penelitian ini adalah data tertulis berupa surat resmi yang dikeluarkan oleh Kantor Desa Mamben Lauk. Sedangkan, sumber data didapatkan dari dokumentasi surat keluar yang ada di Kantor Desa Mamben.

Teknik pengumpulan data yang digunakan dalam penelitian ini adalah teknik dokumentasi, yakni peneliti mengumpulkan dan mencatat berbagai bentuk kesalahankesalahan gramatika yang ditemukan dalam surat resmi dan melakukan pengelompokan atau pengklsifikasian sesuai dengan jenis masalah yang penulis temukan.

Instrumen dalam penelitian ini adalah peneliti sendiri yang melakukan penelitian dalam memperoleh data (Sugiono 2010: 61). Kedudukan peneliti dalam penelitian kualitatif sebagai perencana, pelaksana, pengumpul data, penganalisis, penafsir data, dan pada akhirnya sebagai menjadi pelapor hasil penelitiannya (Moleong 2014: 168). Adapun, data dalam penelitian ini dianalisis secara deskriptif kualitatif, yakni data dideskripsikan dalam bentuk kata-kata atau kalimat dengan menguraikan kesalahan penulisan bagian-bagian surat resmi yang dikeluarkan oleh Kantor Desa Mamben Lauk pada bulan Agustus tahun 2015. 


\section{TEMUAN DAN PEMBAHASAN}

\section{Gramatika dalam Surat Resmi}

Gramatika disebut juga dengan tata bahasa. Adapun tata bahasa adalah ilmu yang mempelajari kaidah-kaidah yang mengatur penggunaan bahasa (Wikipedia, ensiklopedia bebas). Merujuk dari pengertian tersebut yang dimaksud dengan gramatika adalah aturan atau kaidah dalam berbahasa yang benar. Berbahasa Indonesia yang benar adalah bahasa Indonesia yang mematuhi kaidah bahasa Indonesia yang berlaku. Kaidah tersebut meliputi kaidah ejaan, pembentukan kata, penyusunan kalimat, penyusunan paragraf dan penataan penalaran. Jika kaidah ejaan, kaidah pembentukan kata, dan penataan penalaran digunakan dan ditaati dengan konsisten, pemakaian bahasa Indonesia dapat dikatakan benar. Sebaliknya jika kaidah-kaidah bahasa itu kurang ditaati, pemakaian bahasa tersebut dianggap tidak benar (Zaenal, Arifin dan Farid, Hadi. 2009: 12).

Surat resmi adalah surat yang berisi masalah kedinasan atau administrasi pemerintah. Surat dinas/resmi dibuat oleh instansi pemerintah dan dikirimkan kepada semua pihak yang memiliki kepentingan dengan instansi tersebut (Soedjito dan Solchan 2004:14). Surat resmi harus ditulis dengan mengikuti kaidah garamatika bahasa Indonesia yang baik dan benar.

Kalimat surat resmi harus ditulis secara singkat, jelas, dan enak dibaca tanpa mengabaikan kaidah gramatika bahasa Indonesia. Kalimat yang singkat memiliki peluang untuk tidak mengungkapkan maksud secara bertele-tele. Sedangkan, kalimat yang menarik dan enak dibaca adalah kalimat yang sopan, simpatik, tidak bernada menghina atau meremehkan (Afra Tien Setyaningrum, 2008: 73).

\section{Sistematika dan Kaidah Penulisan Bagian Surat Resmi/Surat Dinas}

Arifin Zaenal dan Farid Hadi mengemukakan sistematika dan kaidah dalam penulisan surat resmi berdasarkan EYD bahasa Indonesia sebagai berikut: 


\section{a. Kepala Surat}

Kepala surat yang lengkap terdiri atas (a) nama kantor, (b) alamat, (c) nomor telepon (apabila ada), (d) nomor kotak pos (apabila ada), (e) alamat kawat, (f) lambang/logo, nama kantor cabang, nama bankir, bidang usaha, dan logo.

\section{b. Nomor, Lampiran, dan Perihal Surat}

Kata nomor, lampiran, dan hal ditulis dengan huruf awal kapital, dan diikuti dengan tanda titik dua.

\section{c. Tanggal Penulisan Surat}

Tanggal surat ditulis lengkap yang mencakup tanggal, bulan dan tahun. Misalkan nama bulan tidak disingkat, yang seharusnya Oktober disingkat menjadi Okt.

\section{d. Alamat Surat}

1) Alamat tidak diawali kata kepada, sebab siapa pun sudah mengetahui bahwa alamat yang ditulis itu adalah alamat yang dituju. Selain itu, kata kepada berfungsi sebagai kata penghubung intrakalimat yang menyatakan tujuan, sedangkan alamat surat bukan berupa kalimat, sama halnya dengan alamat pengirim yang tidak perlu menggunakan kata dari.

2) Alamat pada lembar surat ditulis di sebelah kiri di antara perihal dan salam pembuka dengan tidak diikuti tanda baca apapun.

3) Kata sapaan seperti Saudara, Bapak, Ibu, dan Tuan tidak perlu ditulis di depan gelar, pangkat dan jabatan. Kata sapaan digunakan jika diikuti langsung oleh nama orang yang dituju.

\section{e. Penulisan Salam Pembuka}

Salam pembuka yang lazim digunakan yaitu ungkapan Dengan hormat (dengan D kapital, h kecil, diikuti tanda koma); Salam sejahtera (Dengan S kapital, s kecil, diikuti tanda koma). 


\section{f. Penulisan Paragraf Pembuka}

Beberapa kesalahan dalam kalimat yang biasa dipakai oleh penyusun surat diantaranya:

1) Bersama ini kami beritahukan bahwa....

Kesalahan dalam kalimat di atas adalah penggunaan bersama ini, padahal surat tersebut hanya memberitahukan sesuatu, dan tidak melampirkan atau mengirimkan barang.

2) Kami mohon bantuan daripada Tuan.....

Kesalahan dalam kalimat di atas adalah penggunaan daripada, karena daripada hanya digunakan untuk membandingkan dua hal/masalah.

3) Menunjuk pembicaraan kita melalui telepon tanggal.....

Penggunaan bentuk reduce (inggris) menunjuk pembicara. Dalam bahasa Indonesia bentuk tersebut termasuk keterangan cara atau keterangan tujuan yang harus dilengkapi dengan kata penghubung yakni dengan dan untuk.

\section{g. Isi surat}

Isi surat sebagai inti surat harus memakai kata-kata yang jelas tidak multi tafsir atau bermakna ambigu. Menurut Zaenal Arifin dan Farid Hadi (2010: 243) "Isi atau pokok surat memuat sesuatu yang diberitahukan, dilaporkan, ditanyakan, diminta dan lain-lain. Untuk menghindari salah tafsir dan demi efisiensi, isi surat hendaknya harus singkat dan jelas".

\section{h. Penulisan paragraf penutup}

Paragraf penutup sering dijumpai pemakaian kalimat berikut:

Atas perhatiannya, kami ucapkan terimakasih.

Penggunaan akhiran nya pada perhatiannya. Akhiran nya digunakan sebagai kata ganti orang ketiga, sedangkan penerima surat adalah orang kedua. Kata ganti nya dapat diganti dengan Saudara, bapak atau ibu sebagai kata ganti orang kedua. 


\section{i. Salam Penutup}

Salam penutup surat dinas/formal pemerintahan menyebutkan nama jabatan, tanda tangan, nama terang, NIP (Nomor Induk Pegawai).

\section{j. Tembusan Surat}

Tembusan adalah pihak-pihak yang mendapat tembusan/salinan surat selain yang dialamatkan. Kata tembusan ditulis dengan huruf awal huruf kapital dan diikuti tanda titik dua, tanpa digarisbawahi.

\section{Ciri-Ciri Bahasa Surat}

Bahasa surat memiliki ciri-ciri yaitu menggunakan bahasa baku dan bahasa efektif Soedjito dan Solchan 2004: 30) untuk lebih lengkapnya, lihat pembahasan berikut ini:

\section{a. Bahasa baku}

Bahasa baku ialah bahasa yang diakui benar menurut kaidah yang sudah dilazimkan (Soedjito dan Solchan 2004: 31). E. Kosasih menjabarkan ciri-ciri bahasa baku antara lain 1) tidak dipengaruhi bahasa daerah. 2) tidak dipengaruhi bahasa asing. 3) bukan merupakan ragam bahasa percakapan. 4) memakai imbuhan secara eksplisit. 5) pemakaian yang sesuai dengan konteks kalimat. 6) tidak terkontaminasi/tidak rancu .7) tidak mengandung arti pleonasme. 8) tidak mengandung hiperkorek.

\section{b. Bahasa Efektif}

"Bahasa efektif adalah bahasa yang secara tepat dapat mencapai sasarannya. Bahasa efektif dapat dikenali dari pemakaian bahasa yang sederhana/wajar, ringkas, jelas, sopan dan menarik." (Soedjito dan Solchan, 2004: 33).

\section{Penggunaan EYD (Ejaan Yang Disempurnakan)}

"Ejaan adalah keseluruhan peraturan tentang pelambangan bunyi ujaran dan hubungan antara lambang-lambang itu. Secara garis besar, ejaan berkaitan dengan pemakaian dan penulisan huruf, penulisan unsur serapan dan pemakaian tanda baca (Kosasih 2003: 200)". Selanjutnya menurut Stiyawati (2010 : 139), ejaan adalah kaidahkaidah penggambaran bunyi-bunyi (kata, kalimat dan sebagainya) dalam bentuk tulisan (huruf-huruf) serta penggunaan tanda baca. Dari beberapa penjelasan tersebut dapat 
disimpulkan, bahwa ejaan adalah keseluruhan peraturan atau kaidah pemakaian lambang bunyi-bunyi yang meliputi pemakaian dan penulisan huruf, kata, kalimat, penulisan unsur serapan dan pemakaian tanda baca dalam bentuk tulisan.

\section{Kalimat}

\section{a. Pengertian kalimat}

Kalimat adalah satuan bahasa terkecil, dalam wujud lisan atau tulisan, yang mengungkapkan pikiran utuh (Alwi, Hasan dkk. 2010: 317). Selanjutnya Noerzisri (2006 : 14) Kalimat merupakan satuan bahasa yang bersifat predikatif yang idenya sudah lengkap untuk satuan tersebut. Dari beberapa penjelasan di atas dapar disimpulkan, bahwa kalimat adalah satuan bahasa terkecil bersifat predikatif yang mengungkapkan pikiran utuh dalam wujud lisan atau tulisan. Oleh karena itu, kalimat yang sempurna atau efektif akan mampu berdiri sendiri terlepas dari konteksnya, serta mudah dipahami maksudnya.

\section{b. Beberapa Bentuk Kesalahan dalam Bidang Kalimat}

Styawati (2010: 76) memaparkan beberapa penjelasan dan contoh kesalahan dalam bidang kalimat antara lain:

1) Kalimat Tidak Bersubjek

Kalimat yang subjeknya tidak jelas biasa terdapat dalam kalimat rancu, yaitu kalimat yang berpredikat verba aktif transitif di depan subjek terdapat preposisi.

2) Penggandaan Subjek

Penggadaan subjek kalimat menjadikan kalimat tidak jelas bagian yang mendapat tekanan. Contoh:

Persoalan itu kami sudah membicarakannya dengan Bapak Direktur.

Kata atau kelompok kata dalam sebuah kalimat akan menduduki fungsi sintaksis tertentu. Kalimat di atas merupakan kalimat yang tidak baku karena tidak mempunyai subjek. Perbaikan kalimat diatas dapat dilakukan dengan cara: a) diubah menjadi kalimat pasif bentuk diri. b) diubah menjadi kalimat normatif c) salah satu diantara subjek itu dijadikan keterangan.

3) Antara predikat dan objek yang tersisipi

Dalam kalimat transitif, yaitu kalimat yang memiki objek; verba transitif tidak perlu diikuti oleh preposisi sebagai pengantar objek. Adapun contoh kalimat yang di antara predikat dan objek tersisipi preposisi sebagai berikut: 
Kami mengharap atas kehadiran Saudara tepat pada waktunya.

Kalimat di atas dapat diperbaiki menjadi:

Kami mengharapkan kehadiran Saudara tepat pada waktunya.

4) Kalimat yang tidak logis

"Ketidaklogisan kalimat adalah kalimat yang tidak masuk akal. Hal ini terjadi

karena kekuranghatian penulis dalam memilih kata sehingga menyebabkan terjadinya kalimat yang tidak masuk akal" (Stiyawati 2010: 83).

5) Kalimat yang ambiguitas. Ambiguitas adalah kegandaan arti kalimat, sehingga meragukan atau sama sekali tidak dipahami oleh orang lain.

6) Penghilangan Konjungsi

Konjungsi jika, apabila, setelah, sesudah, ketika, karena, dan sebagainya sebagai penanda anak kalimat ditanggalkan. Dalam bahasa Indonesia konjungsi pada anak kalimat harus digunakan. Adapun contoh kalimat yang merupakan gejala penghilangan konjungsi adalah sebagai berikut:

Sering digunakan untuk kejahatan, komputer ini kini dilengkapi pula dengan alat pengaman.

Kalimat di atas dapat diperbaiki menjadi:

Karena sering digunakan untuk kejahatan, komputer ini dilengkapi pula dengan alat pengaman.

7) Penggunaan konjungsi yang berlebihan

Kekurangcermatan pemakai bahasa dapat mengakibatkan penggunaan konjungsi yang berlebihan. Hal itu terjadi karena dua kaidah bahasa bersilang dan bergabung daam sebuah kalimat. Contoh:

Walaupun dia belum istirahat seharian, tetapi dia datang juga dipertemuan RT.

Kalimat di atas dapat diperbaiki menjadi:

Walaupun dia belum istirahat seharian, dia datang juga di pertemuan RT.

8) Urutan yang tidak pararel

Jika dalam sebuah kalimat terdapat beberapa unsur yang dirinci, rincian itu diusahakan pararel. Jika unsur pertama berupa nomina, unsur berikutnya juga berupa nomina, unsur pertama bentuk $d i-\ldots-k a n$, unsur berikutnya juga berbentuk $d i-\ldots-k a n$, dan sebagainya.

Contoh kalimat yang tidak pararel atau tidak sejajar sebagai berikut adalah: 
Dengan penghayatan yang sungguh-sungguh terhadap propesinya serta memahami akan tagas yang diembannya, Dokter Joko telah berhasil mengakhiri jabatannya dengan baik.

Kalimat di atas dapat diperbaiki menjadi:

Dengan penghayatan yang sungguh-sungguh terhadap profesinya serta Pemahaman akan tugas yang diembannya, Dokter Joko telah berhasil mengakhiri jabatannya dengan baik.

9) Penggunaan istilah asing

10) Penggunaan kata tanya yang tidak perlu

Dalam bahasa Indonesia sering dijumpai penggunaan bentuk-bentuk dimana, yang mana, hal mana, dari mana dan kata-kata tanya yang lain sebagai penghubung atau dalam kalimat berita (bukan kalimat tanya). Contoh:

Sektor pariwisata yang mana merupakan tulang punggung perekonomian negara harus ditingkatkan.

Kalimat di atas dapat diperbaiki menjadi:

Sektor pariwisata yang merupakan tulang punggung perekonomian negara harus ditingkatkan.

Berdasarkan hasil analisis dari surat resmi yang dikeluarkan oleh Kantor Desa Mamben Lauk, didapatkan banyak terjadi kesalahan gramatika dalam tiap-tiap bagian surat. Penulis menjabarkan secara detail kesalahan penggunaan gramatika pada tiap-tiap bagian surat resmi. Bagian-bagian surat yang tidak memerlukan analisis karena sudah dianggap benar, tidak dicantumkan. Sebagai contoh berikut dipaparkan mengenai kesalahan-kesalahan gramatika dalam tiap-tiap bagian surat resmi yang dikeluarkan oleh Kantor Desa Mamben Lauk.

\section{Surat Undangan, Tertanggal 26 Januari 2015.}

Berikut analisis kesalahan gramatika pada tiap-tiap bagian surat tersebut:

\section{a. Kepala surat}

\section{Bentuk tidak baku}

\section{Hasil analisis:}


Kepala surat di atas hanya memuat nama instansi, sedangkan penulisan kepala surat yang benar selain nama instansi, kepala surat resmi juga harus memuat alamat, nomor telepon (apabila ada), nomor kotak pos (apabila ada), dan logo (Zainal Arifin dan Farid Hadi, 2009 : 235. Sehingga kepala surat di atas dapat diperbaiki menjadi:

\title{
Bentuk baku
}

\author{
PEMERINTAH KABUPATEN LOMBOK \\ TIMUR \\ LOGO KECAMATAN WANASABA \\ DESA MAMBEN LAUK \\ Jalan Labuan Lombok Km 58, Wanasaba, Lombok Timur, kode pos 38658
}

\section{b. Nomor, lampiran dan hal surat}

\section{Bentuk tidak baku}

Nomor : 003/ / Trantib/2015

Lamp :-

Hal : Panggilan I

\section{Hasil analisis:}

1) Nomor surat

1. Terdapat penulisan garis miring yang kurang tepat pada nomor surat tersebut. Garis miring tidak didahului dan diakhiri spasi.

2. Penempatan urutan nomor surat berdasarkan peraturan kepala arsip nasional republik Indonesia nomor 2 tahun 2014 tentang pedoman tata naskah dinas disebutkan secara berurutan sebagai berikut: kategori klasifikasi keamanan surat, nomor urut surat, kode klsifikasi surat, nama lembaga, bulan dan tahun. Jika kita melihat dalam nomor surat tersebut tidak terdapat kategori kode klasifikasi keamanan, Kode klasifikasi surat dan bulan surat.

2) Lampiran surat

1. Penulisan lampiran surat seharusnya ditiadakan, karena fungsinya tidak jelas, sehingga penulisan lampiran di atas terasa sangat dipaksakan. Tanpa sesuatu yang dilampirkan, kata lampiran tidak harus dicantumkan (Zainal Arifin dan Farid Hadi, 2009 : 237).

2. Penyingkatan kata Lamp. tidak mengikuti kaidah. Jika penulisan kata Nomor tidak disingkat, maka penulisan kata Lampiran dan Perihal surat juga tidak disingkat (Soedjito dan Solchan, 2004 : 44). 
Penulisan nomor, lampiran dan perihal surat tersebut dapat diperbaiki menjadi:

\section{Bentuk baku}

Nomor : kode klasifikasi keamanan surat/03/400-Trantib/0I/2015

Hal : Panggilan I

c. Alamat surat

\section{Bentuk tidak baku}

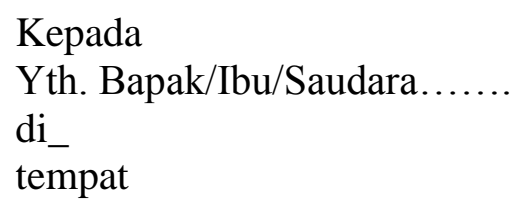

\section{Hasil analisis}

1) Penulisan alamat surat sebaiknya ditulis pada jarak tengah antara hal dan salam pembuka. Posisi alamat di sebelah kiri lebih menguntungkan daripada dituliskan di sebelah kanan karena kemungkinan pemenggalan atau penyingkatan alamat tidak ada. Jadi, alamat panjang pun dapat dituliskan tanpa dipenggal atau disingkat karena tempatnya cukup leluasa.

2) Alamat surat disebutkan berturut-turut:

a) Nama orang/jabatan

b) Nama jalan dan nomor rumah/gedung

c) Nama kota

(Soedjito dan Solchan, 2004 : 45).

3) Kata kepada dan di pada alamat surat tidak perlu dituliskan, sebab tanpa kata kepada sudah jelas kepada siapa surat itu ditujukan. Selain itu, kata kepada berfungsi sebagai kata penghubung intrakalimat yang menyatakan tujuan, sedangkan alamat surat bukan kalimat (Zainal Arifin dan Farid Hadi, 2009 : 238).

Penulisan alamat surat di atas dapat diperbaiki sebagai berikut:

\section{Bentuk baku}

Yth. Bapak/Ibu/Saudara.........

Jalan......

$\operatorname{Kota}(\ldots)$ 


\section{d. Isi surat sesungguhnya}

\section{Bentuk tidak baku}

Dengan ini kami mengundang Bapak/Ibu/Saudara nanti pada:

Hari/Tanggal : Rabu, 28 Januari 2015

Jam : 08.30 Wita

Tempat : : Aula Kantor Desa Mamben Lauk

Guna menyelesaikan permasalahan pembelian (jual beli) Tanah sawah yang terletak di Subak Juet Desa Mamben Lauk.

\section{Hasil analisis}

1) Penulisan hari, jam, dan tempat tidak diawali menggunakan huruf kapital, karena lanjutan dari kalimat sebelumnya.

2) Waktu mulai sampai waktu berahir acara lebih baik ditulis, supaya penerima undangan tidak bertanya waktu berahir acara.

3) Penggunakan kata jam pada surat tersebut kurang tepat seharusnya diganti dengan kata pukul, karena kata jam menunjukkan jangka waktu, sedangkan kata pukul menunjukkan waktu (Zainal Arifin dan Farid Hadi, 2009 : 86).

Jadi, Penulisan isi surat tersebut dapat diperbaiki menjadi:

\section{Bentuk baku}

Dengan ini kami mengundang Bapak/Ibu/Saudara nanti pada:

hari/tanggal : Rabu, 28 Januari 2015

pukul : 08.30 Wita - selesai

tempat : Aula Kantor Desa Mamben Lauk

Guna menyelesaikan permasalahan pembelian (jual beli) Tanah sawah yang terletak di Subak Juet Desa Mamben Lauk.

\section{e. Kalimat penutup}

\section{Bentuk tidak baku}

Demikian untuk maklum dan atas kehadirannya disampaikan banyak terima kasih.

\section{Hasil analisis}

1. Penggunaan kata dasar maklum tanpa penaruhan imbuhan masih ambigu, sehingga perlu ditambahkan imbuhan di-i menjadi dimaklumi.

2. Dalam EYD setiap akhir kalimat dibubuhi tanda titik, sedangkan kalimat tersebut tidak diahiri dengan tanda titik. Paragraf penutup surat tersebut dapat diperbaiki menjadi: 


\title{
Bentuk baku
}

Demikian untuk dimaklumi, atas kehadirannya disampaikan terima kasih.

\section{f. Salam penutup}

\section{Bentuk tidak baku}

\author{
Kepala Desa Mamben Lauk \\ Tanda tangan \\ HANAN, SE, MM
}

\section{Hasil analisis}

1. Salam penutup surat dinas menyebutkan nama jabatan, tanda tangan, nama terang dan NIP (apabila ada) (Soedjito dan Solchan, 2004 : 59).

2. Ada beberapa kesalahan penulisan ejaan yang terjadi pada penulisan nama dan gelar, yaitu: HANNAN, SE, MM, seharusnya ditulis Hannan, S.E., M.M.

Salam penutup surat tersebut dapat diperbaiki menjadi:

\section{Bentuk baku}

\author{
Kepala Desa Mamben Lauk \\ Tanda tangan/cap \\ Hannan, S.E., M.M.
}

\section{SIMPULAN}

Bentuk-bentuk kesalahan penulisan bagian-bagian surat resmi dari surat resmi yang dikeluarkan oleh Kantor Desa Mamben Lauk dari bulan Januari sampai bulan April tahun 2015 meliputi kesalahan dalam bidang ejaan, pilihan kata dan bahasa surat yang digunakan. Bentuk kesalahan ejaan ditemukan dalam hal penulisan huruf kapital, tanda baca, penulisan kata, penulisan singkatan, akronim dan penulisan unsur serapan. Sedangkan, dari segi pilihan kata ditemukan kesalahan berupa pemakaian atau pemilihan kata yang kurang cermat. Adapun dari segi bahasa ditemukan bentuk penggunan bahasa yang kurang efektif dalam kalimat-kalimat surat.

Melihat banyaknya bentuk-bentuk kesalahan penggunaan gramatika, khususnya bentuk kesalahan penulisan bagian-bagian surat resmi di Kantor Desa Mamben Lauk, tidak menutup kemungkinan kesalahan dalam bentuk yang sama terjadi pula di badanbadan instansi pemerintah yang lain. Kesalahan-kesalahan tersebut kemungkinan terjadi 
karena ketidakcermatan dan kekurangpengetahuan penulis surat resmi mengenai kaidahkaidah penulisan gramatika dalam surat resmi.

Surat resmi yang dikeluarkan oleh instansi pemerintah memiliki peran penting sebagai salah satu bentuk upaya pengenalan kepada masyarakat tentang kaidah-kaidah gramatika bahasa Indonesia yang baik dan benar. Oleh sebab itu, bagi penulis surat resmi, khususnya yang bertugas dalam lembaga pemerintahan diharapkan dapat memahami terlebih dahulu kaidah-kaidah penulisan surat resmi dan pemakaian gramatika dalam surat resmi.

\section{DAFTAR PUSTAKA}

Alwi, H. et al. (2010). Tata bahasa baku bahasa Indonesia edisi ketiga. Jakarta: Balai Pustaka.

Arifin, Z., \& Hadi, F. (2009). Seribu satu kesalahan berbahasa. Jakarta: Akapress.

Kosasih, E. (2003). Ketatabahasaan dan kesusastraan. Bandung: Yrama Widya.

Moleong. (2014). Metodologi penelitian kualitatif. Bandung: PT Remaja Rosdakarya.

Soedjito \& Solchan. (2004). Surat menyurat resmi bahasa Indonesia. Bandung: PT Remaja Rosdakarya.

Styawati, N. (2010). Analisis kesalahan berbahasa Indonesia teori dan praktik. Surakarta: Yuma Pustaka.

Sugiono. (2013). Metode penelitian kuantitatif, kualitatif dan $R \& D$. Bandung: Alfabeta.

Tien, A.S. (2008). Korespondensi Bahasa Indonesia. Yogyakarta: Amara Books. Sugiono. 2013. Metode Penelitian Kuantitatif, Kualitatif dan R\&D. Bandung: Alfabeta. 